\title{
BURKITT'S LYMPHOMA IN THE APPENDICULAR SKELETON
}

\author{
JOHN V. FOWLES, C. L. M. OLWENY, E. KATONGOLE-MBIDDE, A. LUKANGA-NDAWULA, R. OWOR
}

\section{From the Lymphoma Treatment Centre at the Uganda Cancer Institute, Makere University Medical School, and Mulago Hospital, Kampala}

Of 290 Ugandan children and adolescents with proven Burkitt's lymphoma 11 had lesions in the long bones or the pelvis. These started in the medulla as small osteolytic foci which coalesced and penetrated the cortex causing subperiosteal new bone formation in layers or spicules, and giving rise to large soft-tissue masses. Common sites were the femoral and tibial diaphyses and the metaphyses around the knee. Five were in the epiphyses. Other sites were the pelvis, humerus and ulna. One patient had a lymphomatous synovial effusion of the knee. In the lower limbs the lesions were often bilateral and symmetrical. Five patients had pathological fractures. Radiologically the lesions mimicked Ewing's sarcoma, osteosarcoma, osteomyelitis, acute leukaemia, syphilis and yaws, but clinically they were relatively painless, an important differential diagnostic feature. In the five patients with sustained remissions after chemotherapy the lesions and fractures healed well and the growth plates were undamaged.

Burkitt's lymphoma is the most common malignant disease of children in tropical Africa and is rapidly fatal if untreated (Burkitt 1958; O'Conor and Davies 1960; Olweny et al. 1976). It has now been recognised in other parts of the world, where it is, however, much less common (Burkitt 1970; Carbone et al. 1971; Sabbah et al. 1982). The endemic African variety differs from the sporadic, non-African type in showing climatic and geographic dependency, a consistent association with the Epstein-Barr virus, low humoral antibody levels, a low

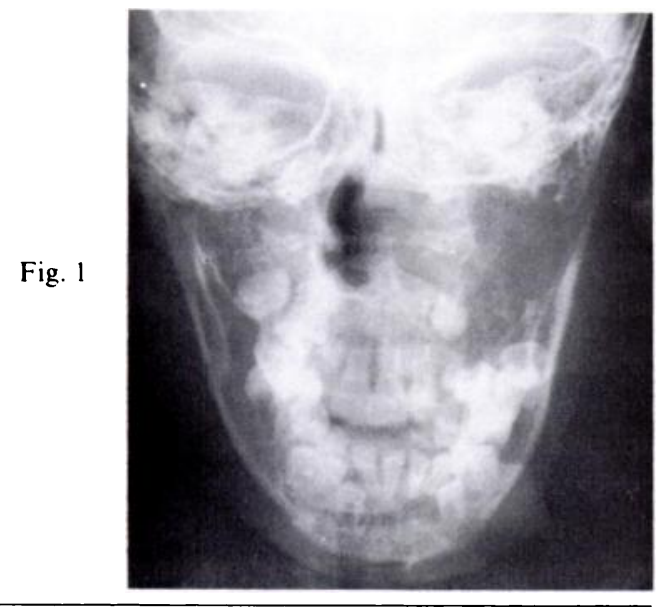

J. V. Fowles, FRCS(C), Professeur adjoint de clinique

Department de Chirurgie, Université de Montréal, Clinique d'Orthopèdie St Urbain, 3875 Rue St Urbain, Suite 209. Montréal, Canada H2W IVI.

Professor C. L. M. Olweny, MMed (EA), MD, Director

E. Katongole-Mbidde, MB ChB, MMed, Director

Uganda Cancer Institute, Kampala, Uganda.

A. Lukanga-Ndawula, MD, FRCS, Chief of Orthopaedic Surgery Mulago Hospital, Kampala, Uganda.

R. Owor, MRCPath, MD, Professor and Head

Department of Pathology, Makere University, Kampala, Uganda.

Requests for reprints should be sent to Dr J. V. Fowles.

(C) 1983 British Editorial Society of Bone and Joint Surgery $0301-620 \mathrm{X} / 83 / 4078 \$ 2.00$ incidence of positive bone-marrow smears, normal peripheral lymph nodes and a predilection for the jaws, particularly the maxilla (Patient 5: Figs 1 to 4; Burkitt

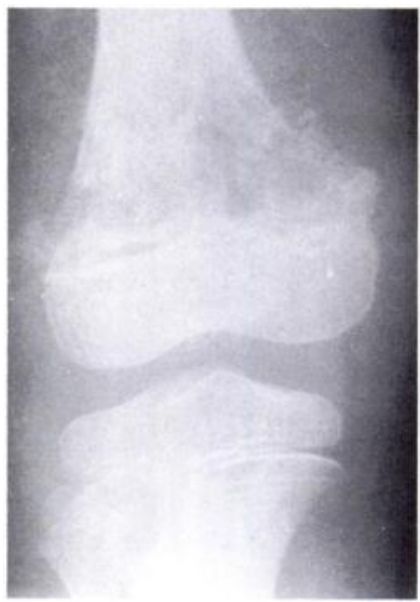

Fig. 2

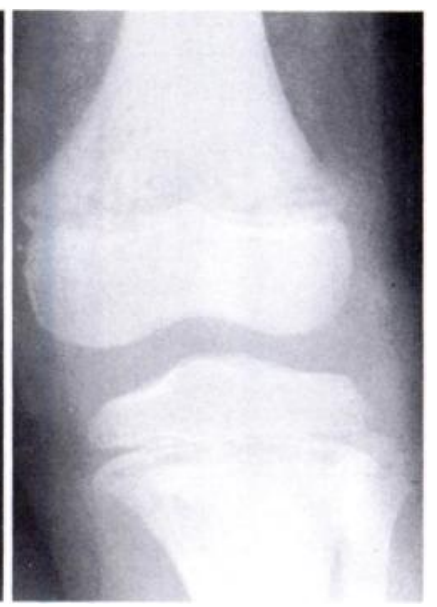

Fig. 3

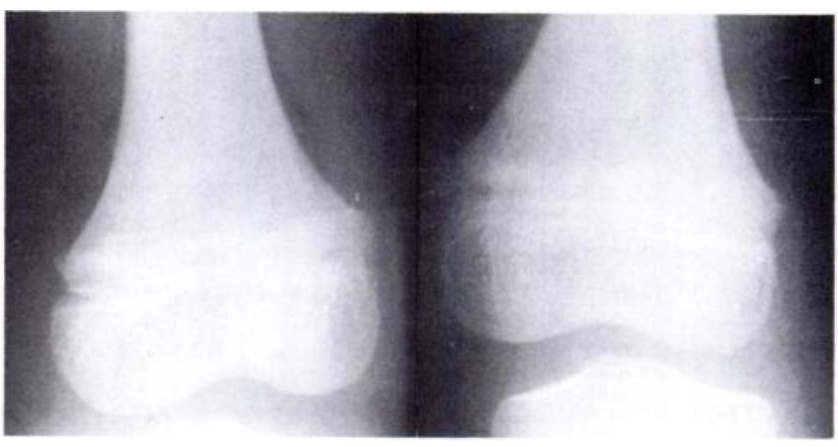

Fig. 4

Patient 5. A seven-year-old boy with a left facial swelling of two weeks duration. Figure 1-There is a lytic lesion of the left maxilla with displacement and loss of some teeth, and absence of the lamina dura in others. Figure 2-The right knee shows advanced destruction of the femoral metaphysis. Figure 3-Radiograph of the left knee showing juxta-epiphysial lucent lines of the metaphyses. Figure 4-After 10 months treatment there is healing of the metaphysial lesions. There had been no recurrence six years later. 
Table I. Clinical and radiographic features of 11 patients with Burkitt's lymphoma in the pelvis or appendicular skeleton

\begin{tabular}{|c|c|c|c|c|c|c|}
\hline Patient & Sex & $\begin{array}{l}\text { Age } \\
\text { (years) }\end{array}$ & Lesions & Radiographic features & $\begin{array}{l}\text { Biopsy and other } \\
\text { operations }\end{array}$ & Clinical course \\
\hline 1 & $\mathrm{~F}$ & 3 & $\begin{array}{l}\text { Maxilla, liver, spleen, } \\
\text { ovary, pelvis. Relapse in } \\
\text { parotid, retroperitoneal } \\
\text { glands, pericardium and } \\
\text { pleura }\end{array}$ & $\begin{array}{l}\text { Lytic expansile lesion of } \\
\text { inferior pubic ramus, cortex } \\
\text { broken. Pericarditis with large } \\
\text { heart shadow }\end{array}$ & $\begin{array}{l}\text { Ovary and jaw + ve. } \\
\text { Unilateral } \\
\text { oöphorectomy, and } \\
\text { pleural aspirates + ve }\end{array}$ & $\begin{array}{l}\text { Good initial response. } \\
\text { Pelvis healed. Relapse. } \\
\text { Died } 17 \text { months after onset }\end{array}$ \\
\hline 2 & $\mathbf{M}$ & 7 & $\begin{array}{l}\text { Large mass in right iliac } \\
\text { fossa, buttock, hip and } \\
\text { thigh; paresis right leg. } \\
\text { Liver and spleen }\end{array}$ & $\begin{array}{l}\text { Ilium destroyed. Separation } \\
\text { through triradiate cartilage. } \\
\text { IVP: bladder displaced. }\end{array}$ & Pelvic mass + ve. & $\begin{array}{l}\text { Good response. Sclerotic } \\
\text { reaction in ilium in healing } \\
\text { phase. Pelvis } \\
\text { radiographically normal } \\
\text { one year later. In remission } \\
\text { at } 129 \text { months }\end{array}$ \\
\hline 3 & $\mathbf{F}$ & 6 & $\begin{array}{l}\text { Maxilla, liver, spleen, } \\
\text { kidney, ovary and } \\
\text { humerus }\end{array}$ & $\begin{array}{l}\text { Mottled, lytic lesions in distal } \\
\text { humeral shaft and metaphysis; } \\
\text { subperiosteal layering }\end{array}$ & $\mathrm{Jaw}+$ ve. $\operatorname{CSF} ?+$ ve & $\begin{array}{l}\text { Good response. Humerus } \\
\text { almost normal } 2 \text { months } \\
\text { later. Not seen since }\end{array}$ \\
\hline 4 & $\mathbf{M}$ & 11 & $\begin{array}{l}\text { Maxilla, both tibiae and } \\
\text { femora. Relapse in } \\
\text { maxilla, tibiae and CSF }\end{array}$ & $\begin{array}{l}\text { Bilateral, symmetrical, } \\
\text { eccentric lesions in distal } \\
\text { femoral metaphysis and } \\
\text { epiphysis. Bilateral central } \\
\text { medullary lesions in tibial shaft } \\
\text { with subperiosteal layering }\end{array}$ & Maxilla + ve. CSF + ve & $\begin{array}{l}\text { Good initial response. } \\
\text { Relapse at } 1 \text { year with good } \\
\text { second response. Bones } \\
\text { nearly normal at } 1 \text { year. } \\
\text { Growth plates open. In } \\
\text { remission at } 106 \text { months }\end{array}$ \\
\hline 5 & $\mathbf{M}$ & 7 & $\begin{array}{l}\text { Maxilla, paralysis VIth } \\
\text { cranial nerve. Liver, } \\
\text { spleen, both femora and } \\
\text { tibiae. Relapse in supra- } \\
\text { orbital region and } \\
\text { intestine }\end{array}$ & $\begin{array}{l}\text { Bilateral, symmetrical lesions } \\
\text { in distal femoral and proximal } \\
\text { tibial metaphyses. Cortex } \\
\text { broken and subperiosteal rays } \\
\text { in left femur }\end{array}$ & $\begin{array}{l}\text { Maxilla + ve. } \\
\text { Laparotomy and } \\
\text { segmental intestinal } \\
\text { resection for } \\
\text { intussusception }\end{array}$ & $\begin{array}{l}\text { Good initial response. } \\
\text { Relapse at } 3 \text { months with } \\
\text { good second response. } \\
\text { Bones healed } 10 \text { months } \\
\text { later with sclerotic reaction. } \\
\text { In remission at } 84 \text { months }\end{array}$ \\
\hline 6 & $\mathbf{M}$ & 10 & $\begin{array}{l}\text { Lumbar mass, spastic } \\
\text { paraplegia. Femur. } \\
\text { Relapse in femur }\end{array}$ & $\begin{array}{l}\text { Central medullary lesion in } \\
\text { shaft and distal metaphysis } \\
\text { femur. Subperiosteal layering } \\
\text { and rays. Lesion in posterior } \\
\text { cortex body and pedicle of L2. } \\
\text { Cisternal and lumbar } \\
\text { myelograms: extradural block } \\
\text { T12 to L3 }\end{array}$ & $\begin{array}{l}\text { Lumbar mass + ve. } \\
\text { CSF + ve }\end{array}$ & $\begin{array}{l}\text { Good initial response. } \\
\text { Paraplegia improved, with } \\
\text { free passage of remaining } \\
\text { dye. Relapse } 7 \text { months } \\
\text { later. Not seen since }\end{array}$ \\
\hline 7 & $\mathbf{M}$ & 3 & $\begin{array}{l}\text { Both femora and tibiae. } \\
\text { Relapse in jaw, spleen, } \\
\text { kidneys, both femora and } \\
\text { tibiae }\end{array}$ & $\begin{array}{l}\text { Lesion in proximal left femur } \\
\text { with intertrochanteric fracture. } \\
\text { Eccentric lesion in right, distal } \\
\text { femoral epiphysis. Bilateral, } \\
\text { symmetrical, central medullary } \\
\text { lesions in tibial shaft and } \\
\text { proximal metaphysis }\end{array}$ & $\begin{array}{l}\text { Right tibia + ve. } \\
\text { Kidneys + ve }\end{array}$ & $\begin{array}{l}\text { Good initial response. } \\
\text { Relapse at } 4 \text { months. Good } \\
\text { second response. In } \\
\text { remission at } 43 \text { months }\end{array}$ \\
\hline 8 & $\mathbf{F}$ & 11 & $\begin{array}{l}\text { Ovaries, liver, spleen. } \\
\text { Relapse in ulna }\end{array}$ & $\begin{array}{l}\text { Streaky lesions in entire ulnar } \\
\text { shaft, cortical destruction, } \\
\text { separation of distal epiphysis, } \\
\text { subperiosteal layering. Large } \\
\text { soft-tissue mass }\end{array}$ & $\begin{array}{l}\text { Ovaries + ve. } \\
\text { Bilateral oöphorectomy. } \\
\text { Ulna + ve }\end{array}$ & $\begin{array}{l}\text { Partial initial response. } \\
\text { Relapse } 7 \text { months later. } \\
\text { Fracture through biopsy } \\
\text { site of ulnar shaft, healed in } \\
\text { cast. In remission at } 7 \\
\text { months }\end{array}$ \\
\hline 9 & $\mathbf{M}$ & 7 & $\begin{array}{l}\text { Maxilla, right knee. } \\
\text { Relapse in right femur } \\
\text { and knee }\end{array}$ & $\begin{array}{l}\text { Large, eccentric lesion in right } \\
\text { distal femoral metaphysis, } \\
\text { separation of distal epiphysis. } \\
\text { Subperiosteal layering and } \\
\text { rays. Effusion of knee }\end{array}$ & $\begin{array}{l}\text { Jaw + ve. Synovium of } \\
\text { right knee + ve }\end{array}$ & $\begin{array}{l}\text { Partial initial response. } \\
\text { Relapse at } 3 \text { months. Good } \\
\text { second partial response. } \\
\text { Not seen since }\end{array}$ \\
\hline 10 & $\mathbf{M}$ & 17 & $\begin{array}{l}\text { Maxilla, mandible. } \\
\text { Flaccid paraplegia. Left } \\
\text { IIIrd and VIth cranial } \\
\text { nerve palsies. Relapse in } \\
\text { maxilla, VIth cranial } \\
\text { nerve, mandible, femur } \\
\text { and tibia }\end{array}$ & $\begin{array}{l}\text { Eccentric lesions in proximal } \\
\text { tibial shaft and metaphysis; } \\
\text { epiphysial separation from } \\
\text { tibial tuberosity; subperiosteal } \\
\text { rays. Ipsilateral distal femoral } \\
\text { metaphysis. Myelogram: block } \\
\text { T8 to L3 }\end{array}$ & $\begin{array}{l}\text { Jaw + ve. } \\
\text { Laminectomy. Peridural } \\
\text { mass + ve. Tibia + ve. } \\
\text { CSF + ve }\end{array}$ & $\begin{array}{l}\text { Partial initial response. } \\
\text { Three relapses. } \\
\text { Radiotherapy for tibia. } \\
\text { Died } 2 \text { years after onset }\end{array}$ \\
\hline 11 & $\mathbf{M}$ & 4 & $\begin{array}{l}\text { Maxilla, bilateral } \\
\text { proptosis, VIth nerve } \\
\text { palsy, mandible. Flaccid } \\
\text { paraplegia. Kidneys, } \\
\text { retroperitoneal mass. } \\
\text { Both femora }\end{array}$ & $\begin{array}{l}\text { Bilateral, symmetrical, streaky } \\
\text { medullary and cortical lesions } \\
\text { in femora from neck to distal } \\
\text { metaphysis; periosteal } \\
\text { layering. Intertrochanteric } \\
\text { fracture. Diastasis of cranial } \\
\text { sutures }\end{array}$ & $\begin{array}{l}\text { Marrow aspirate + ve. } \\
\text { CSF + ve. Autopsy, } \\
\text { diseased tissue + ve }\end{array}$ & $\begin{array}{l}\text { No response to } \\
\text { chemotherapy. Died } 6 \text { days } \\
\text { after admission }\end{array}$ \\
\hline
\end{tabular}

The term "in remission" is preferred to "cure" because of the possibility of relapse. 
and Wright 1966; Burkitt 1969; Ziegler et al. 1970a, Banks et al. 1975; Klein 1975; Olweny et al. 1977; DeThé et al. 1978; Wright 1978; Olweny et al. 1980).

The tumour is multifocal and frequently involves the paired intra-abdominal and pelvic organs, retroperitoneal lymph glands, and the central nervous system; it is the commonest cause of paraplegia in children within the "lymphoma belt" of Africa (Burkitt 1968). Leukaemic changes in the peripheral blood are rare. Lesions of the appendicular skeleton have been briefly noted in the past but have not been described in detail (Burkitt and O'Conor 1961; Wright 1964; Burkitt 1968; Cockshott 1965, 1970; Huckstep 1970).

\section{MATERIAL}

From 1969 to 1979, 290 new patients with proven Burkitt's lymphoma were treated at the Uganda Cancer Institute, Kampala. Eleven of these had pelvic or longbone lesions discernible on radiographs and are reported in this paper. Eight were boys and three girls; their ages ranged from 3 to 17 years (see Table I). The delay between the onset of symptoms and the first medical consultation varied from 2 to 16 weeks. In two patients the presenting feature was the bony lesion; in one (Patient 2) an iliac tumour with swelling of the hip and

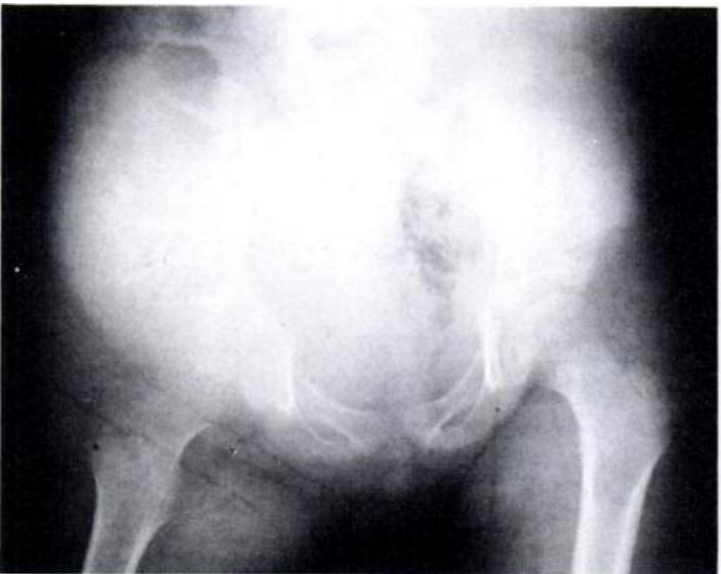

Fig. 5 flaccid; one of these (Patient 6) had vertebral destruction with tumour filling the extradural space; another (Patient 10) had an extensive extradural mass; and the third (Patient 11) had a large retroperitoneal tumour.

The bony lesions were often associated with large soft-tissue swellings (Patient 8; Figs 7 to 11). Patients usually complained of a little pain or ache locally, but tenderness over the mass was not a marked feature, and general malaise and toxaemia were evident only when the disease was well advanced.

Lesions at other sites included the spleen in six patients, the liver in five, both kidneys in two, retroperitoneal glands in two and the intestine in one. One girl with bilateral ovarian disease had a bilateral oöphorectomy and another had one ovary removed. One (Patient 1) had pericardial and pleural effusions containing tumour cells. Seven patients had large, grossly disfiguring tumours of the maxilla and two of the mandible also, causing teeth to loosen or fall out (Fig. 1); three of these patients had cranial nerve palsies.

The diagnosis was proved by open biopsy (Figs 10 and 11) in every patient. Marrow was aspirated from eight patients but was positive in only one; the cerebrospinal fluid, however, contained tumour cells in five of the nine patients who had a lumbar puncture (including all three with paraplegia).

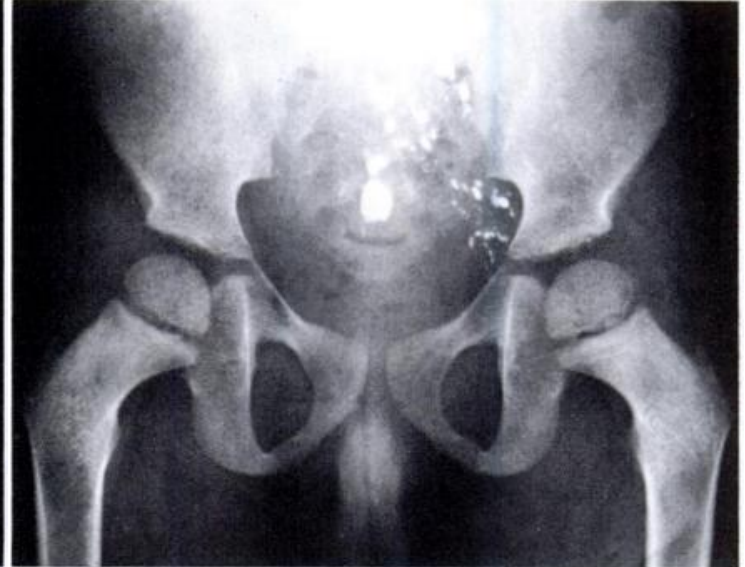

Fig. 6

Patient 2. A seven-year-old boy with a large mass of the right iliac fossa, buttock, hip and thigh, and monoparesis of the right leg. Figure 5-This radiograph, before treatment started, shows a large lytic lesion of the right ilium with unilateral femoral osteoporosis. Figure 6-Eight months after treatment. A myelogram had been done to rule out a cord lesion. The ilium has a normal appearance and the patient has had no recurrence in 10 years.

thigh (Figs 5 and 6), and in the other (Patient 7) a pathological fracture of the femur.

Nine patients presented initially with facial or abdominal swelling and only later developed lesions of the appendicular skeleton. One (Patient 9) with a lesion of the distal femoral metaphysis (see Fig. 13) also had tumour cells in the synovium and synovial fluid of the ipsilateral knee; the swelling of the joint appeared three months before the radiological change.

Three patients were paraplegic, one spastic and two

\section{RADIOLOGICAL FEATURES}

In all, 23 bones were affected, eight extensively. Nine patients had deposits in the lower limbs or pelvis; two had deposits in the upper limbs (Table I). The bone most commonly affected was the femur, which was involved in seven patients; in four the involvement was bilateral and in three of these the radiological changes were symmetrical (Fig. 12). In three of the four children with tibial disease, this was bilateral and symmetrical. The distal femoral or proximal tibial metaphyses were involved in 


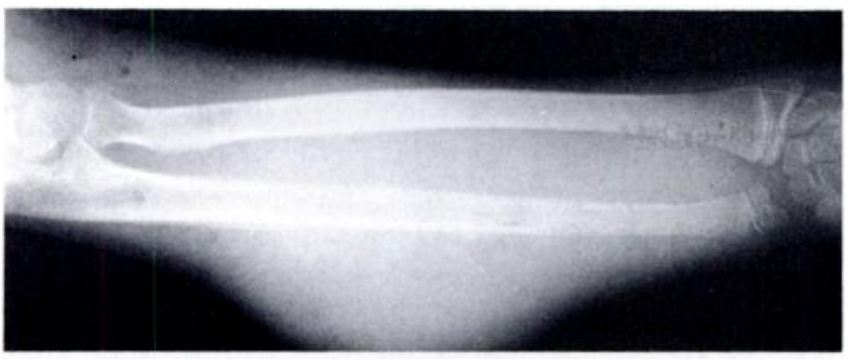

Fig. 7

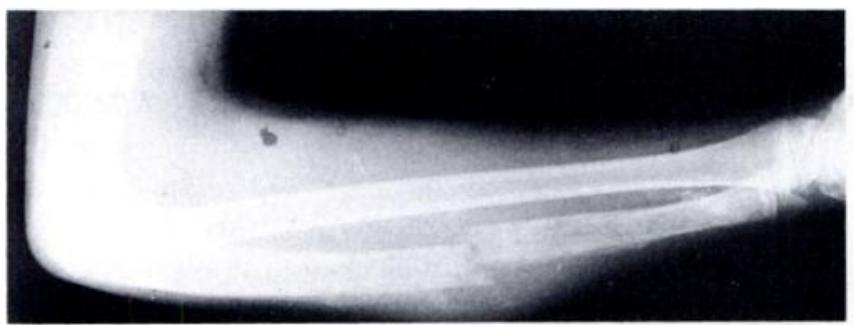

Fig. 8

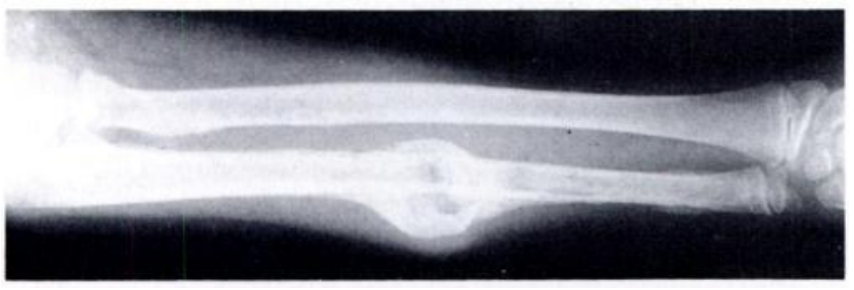

Fig. 9

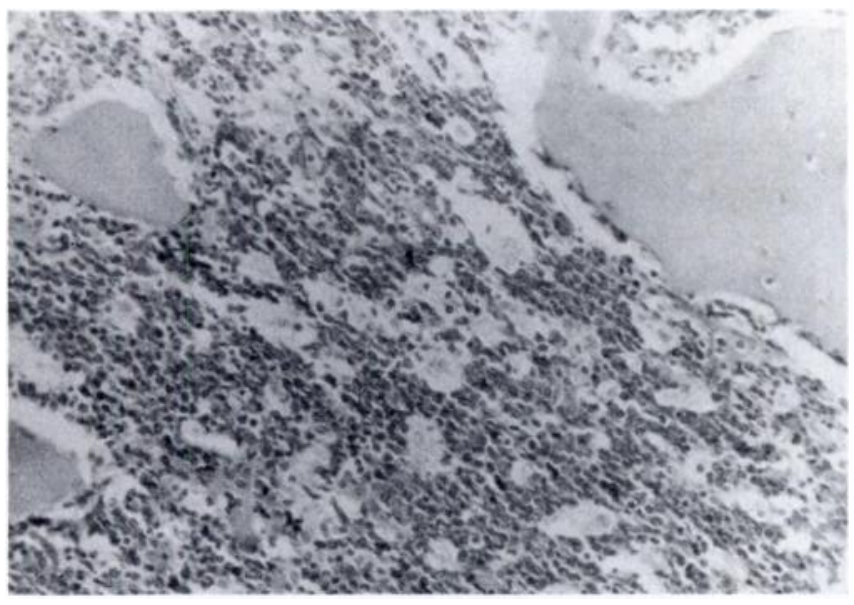

Fig. 10

Fig. 12

Patient 11. A seven-year-old boy with symmetrical involvement of both femora and a pathological fracture on the left. There are spotty and streaky medullary lesions with subperiosteal new bone formation along the shaft, but no periosteal reaction visible along the neck. The patient had multiple tumour masses, was moribund on admission and died shortly afterwards.
Patient 8. An 11-year-old girl who had chemotherapy and bilateral oöphorectomy for an abdominal tumour. Figure 7-Three months after treatment started she developed a painless swelling over the left ulna with streaky, radiolucent lesions of the shaft and a subperiosteal reaction. Figure 8-After fracture through the biopsy site she was treated with chemotherapy and a long-arm cast. The fracture line through the distal ulnar metaphysis is still visible. Figure 9-Two months later the swelling has diminished, the shaft fracture is uniting with abundant callus, and the metaphysial fracture has healed. Figure 10-Section of the tumour in the ulna. The predominant cells are uniform, undifferentiated lymphoid cells with moderate nuclear and cytoplasmic variations, and are no larger than the nucleus of a reactive histiocyte. Macrophages are scattered uniformly throughout the tumour, producing the characteristic "starry sky" pattern. The tumour is invading the spaces between normal bone trabeculae in which osteocytes can be seen. (Haematoxylin and eosin, $\times 5$.) Figure 11-An imprint of the tumour showing a field of tumour cells with a macrophage near the centre. (Haematoxylin and eosin, $\times 12$.) 
12 bones, in four of which the tumour extended into the shaft; in one of these 12 there was a fracture through the distal femoral growth plate (Fig. 13). The femoral neck and trochanteric area were involved in two patients, both of whom had pathological fractures (Fig. 12). Destruction was evident in the distal femoral or proximal tibial epiphysis in five instances.

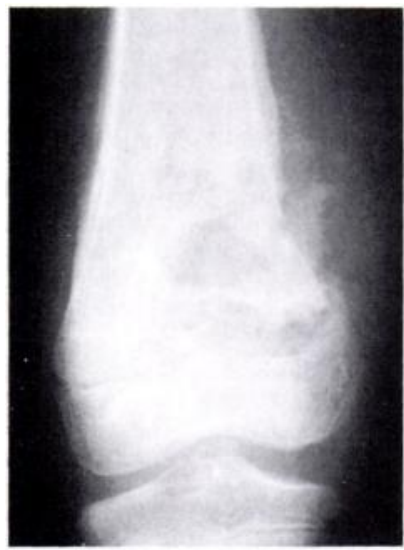

Fig. 13

Patient 9. A seven-year-old boy with a large, eccentric, destructive lesion of the distal femoral metaphysis and areas of cortical destruction eight months after chemotherapy for a facial tumour The distal femoral epiphysis is displaced into valgus.

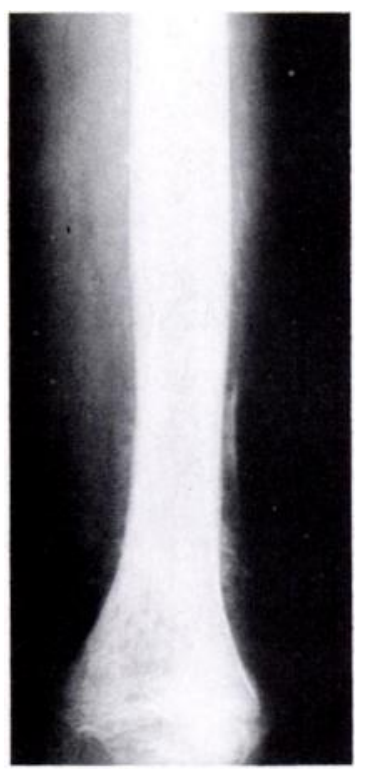

Fig. 14

Patient 6. A 10-year-old boy with paraplegia and extensive involvement of the left femur. There is old and new subperiosteal bone formation in "onion layers" and subperiosteal perpendicular spicules about the metaphysis which shows multiple spotty lesions. The tumour responded only partially to chemotherapy.

The pelvis was the site of deposits in two children. One had a localised, expanded area in the inferior pubic ramus, while in the other the entire ilium was involved with a fracture through the triradiate cartilage, a large soft-tissue mass in the buttock and hip, and a mass inside the pelvis pushing the bladder across the mid-line (Fig. $5)$. In the patient with spastic paraplegia the tumour in the vertebral canal had eroded the posterior surface of the second lumbar vertebral body and partly destroyed a pedicle.

Disease in the upper limb was unilateral. In one child the distal humeral shaft and metaphysis were involved (see Figs 19 and 20), in the other the entire shaft of the ulna with a large, painless soft-tissue mass in the mid-forearm and fractures through the distal metaphysis and the biopsy site (Figs 7, 8 and 9).

The deposits showed as small, multiple osteolytic lesions in the medullary cavity, tending to be streaky in the shaft and mottled or punched out in the metaphysis (Fig. 7 and Fig. 14). In one patient there was a narrow radiolucent band next to the epiphysial plate in the metaphyses about the knee (Fig. 3), and in two patients the lesions had coalesced to destroy half the metaphysis (Fig. 2 and Fig. 13). The margins of the lesions were illdefined with no sclerotic reaction around them. Cortical erosion occurred in the more advanced stages and in four instances the cortex was breached (Fig. 2 and Fig. 13). Half the lesions in the shaft and metaphysis provoked a layered subperiosteal reaction creating the classical "onion skin" pattern (Figs 12, 13, 15, 16, 19 and 20), and two had a "sunburst" appearance, with spicules perpen-

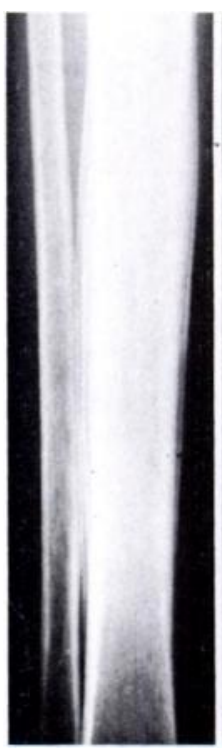

Fig. 15

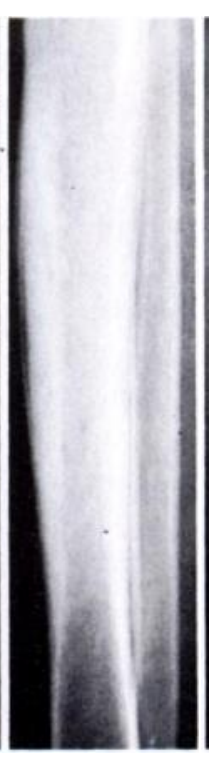

Fig. 16

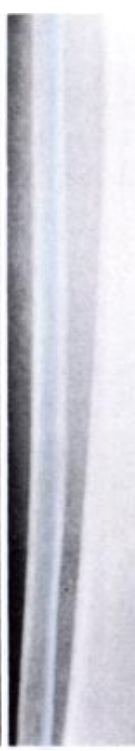

Patient 4. An 11-year-old boy with swelling of the face and tibia for two months before admission. Figures 15 and 16 -Anteroposterior and lateral radiographs of the right tibia on admission show streaky intramedullary lesions with cortical thickening and "onion skin" layering of new bone around the shaft. Figure 17-Nine months after starting treatment the right tibia looks almost normal: the normal left tibia is shown for comparison. Nine years after treatment for central nervous system disease, the patient is still in remission. 
dicular to the cortex (Figs 14 and 18). Lesions in the epiphyses, pelvis and intertrochanteric region had no periosteal reaction.

Some bone lesions were initially diagnosed as Ewing's tumour, osteosarcoma or Pott's disease. Others, which developed during or after treatment, were thought at first to be osteomyelitis or septic arthritis.

\section{TREATMENT AND RESULTS}

One patient (Patient 11) with large, multiple lesions died within a few days of admission. The other 10 were treated by chemotherapy. Cyclophosphamide, methotrexate and vincristine were used in varying combinations (Ziegler 1972; Olweny et al. 1980). Methotrexate and cytosine arabinoside were given by intrathecal injection in patients with disease of the central nervous system and the patient with a synovial tumour had intra-articular injections. Allopurinol was added in all instances to prevent uric acidaemia after rapid lysis of the tumour.

All 10 patients at first improved dramatically; one remained satisfactory, one did not return for follow-up and the other eight relapsed. These eight were given further chemotherapy and again all improved; three have remained well, one did not return for follow-up and four had further relapses. These relapses were again treated by chemotherapy, and one patient (Patient 10) also had radiotherapy (elsewhere); of these four patients one has remained well, two died during treatment and one did not return to hospital.

Five patients were seen an average of six years (minimum seven months, maximum 11 years) after the end of treatment; all were apparently cured with no signs of further recurrence. Their pain had disappeared and the soft-tissue mass had started shrinking, within a few days of starting treatment. The bone lesions also responded rapidly to treatment, the bones remodelling and regaining their normal configuration (Figs 4, 6 and 17). Any fractures healed well with no apparent damage to growth plates.

\section{DISCUSSION}

In Uganda swellings of the jaw are a commoner presenting feature of Burkitt's lymphoma than abdominal tumours, especially in young children. However, in 50 autopsies, Wright (1964) found that the kidneys, ovaries, adrenals and retroperitoneal lymph nodes were involved more frequently than the jaws. This apparent paradox may simply be due to the fact that facial tumours are immediately obvious. Intra-abdominal tumours, however, may reach an enormous size, and surgical reduction of the tumour mass by at least 90 per cent is worth while, since it also improves the results of chemotherapy (Magrath et al. 1974). One girl in our series had large, bilateral ovarian tumours removed with this end in view. Apart from biopsy there is no other indication for surgical excision of the tumour (Burkitt 1968, 1970).

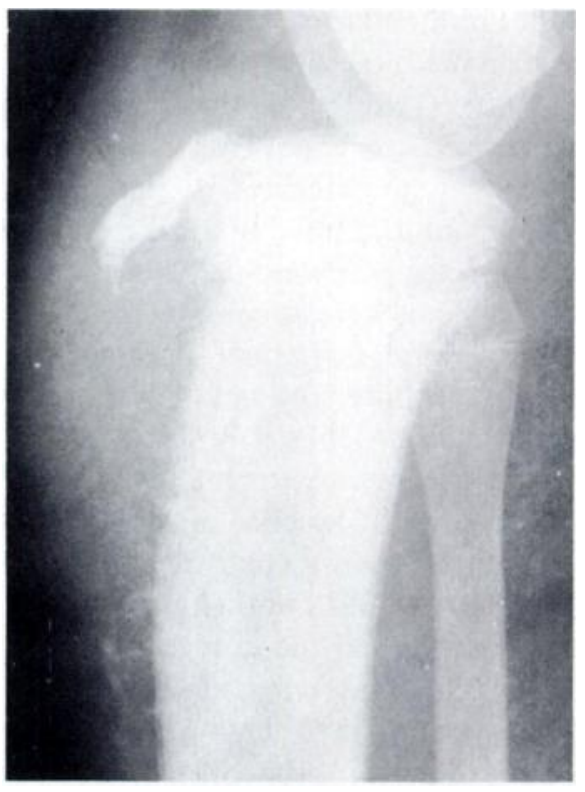

Fig. 18

Patient 10. A 17-year-old male with destruction of the anterior metaphysial cortex of the tibia. This has fractured and elevated the tibial tubercle, and has provoked a sun-ray pattern of new bone formation.

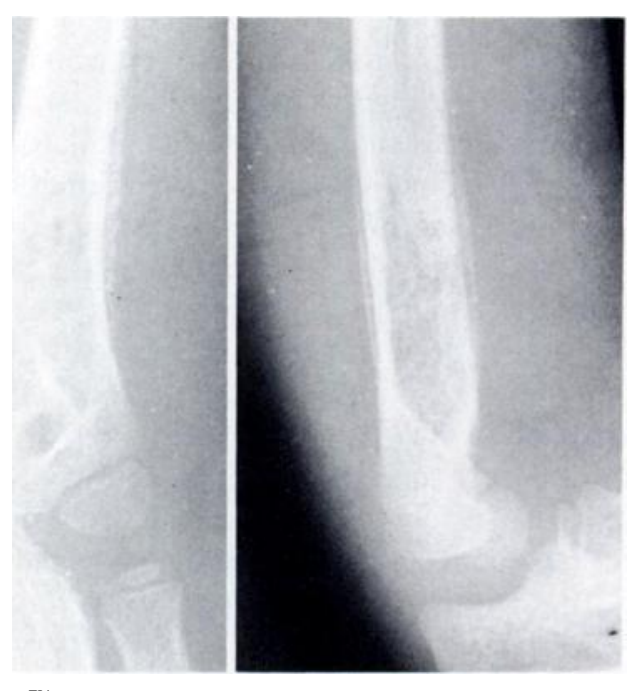

Fig. 19

Fig. 20

Patient 3. Anteroposterior and lateral films of a six-year-old girl with facial and intra-abdominal lesions. There are spotty and streaky lucent areas in the distal humeral metaphysis with subperiosteal reaction in layers.

Wright (1970) reported that tumours of the skeleton other than the jaw occurred in 6.7 per cent of Ugandan patients with Burkitt's lymphoma proven by biopsy; the femur accounted for nearly half of these, followed by the tibia and humerus. Cockshott (1970) made a similar observation in Nigerian patients; long-bone lesions were radiologically detectable in 3.6 per cent of the patients seen during the 11 years of his study. Wright (1964) found tumour deposits in the long bones of 22 per cent of the patients who came to autopsy, but many of these were 
small nodules in the marrow cavity and would not have been visible on plain radiographs.

Berard et al. (1969) stated that skeletal lesions were small and localised. In our patients the bone involvement was sometimes quite extensive. It mainly affected the shafts of the femur and tibia, and the metaphyses about the knee. The epiphyses were involved in five patients, but the growth plates were apparently unaffected. A joint was involved in only one patient. Pathological fractures may be an early feature (Braband 1968) and two of our patients presented in this way; four other fractures occurred during or after treatment.

The radiological lesions in this present study occasionally mimicked other diseases, and some were misdiagnosed at first. The radiolucent mottling of the humeral metaphysis and the thin layer of subperiosteal bone around it in Figures 19 and 20 are similar to the early changes seen in acute haematogenous osteomyelitis. The osteolytic lesions, subperiosteal new bone, and cortical infiltration seen in Figure 14 resemble the features of Ewing's sarcoma (Sherman and Soong 1956). The osteolytic and osteoblastic reaction, cortical destruction, and "sunburst" pattern of subperiosteal new bone formation in Figure 18 are similar to those of an osteogenic sarcoma (Spjut et al. 1971). The radiolucent juxta-epiphysial bands in Figure 3 could be mistaken for the early skeletal manifestations of acute leukaemia (Jaffe 1958). The tibial changes of Patient 4 (Figs 15 and 16) are similar to those of yaws or of late congenital syphilis, with subperiosteal new bone formation over the middle of the shaft (Wynne-Davies and Fairbank 1976).

Chemotherapy renders the patient more susceptible to infection and new bone lesions appearing during treatment may be mistaken for osteomyelitis. The lesions in Figure 7, for example, appeared less than six weeks after chemotherapy for ovarian tumours. Streaky medullary and cortical destruction in the ulnar shaft and metaphysis, surrounded by successive layers of subperiosteal new bone, suggested a radiographic diagnosis of acute pyogenic diaphysitis. Biopsy proved the true nature of the lesion (Figs 10 and 11). Another patient in remission for eight weeks after chemotherapy developed a swollen knee which was diagnosed clinically as septic arthritis until aspiration of the synovial fluid showed the presence of tumour cells.

This diagnostic dilemma attests to the fact that bone lesions in Burkitt's lymphoma are uncommon and have no pathognomonic radiographic characteristics (Cockshott 1970). Clinical features, however, are diagnostically helpful. They include the marked absence of severe pain, tenderness or local inflammation, normal regional lymph nodes and peripheral white cell count, the absence of toxaemic symptoms and the presence of rapidly growing tumours in other typical sites. Most of the patients reported here were under 10 years old, younger than with most other primary tumours in bone.

Paraplegia is usually caused by extradural tumour deposits arising either from a vertebra or from a retroperitoneal or posterior mediastinal tumour mass extending through a neural foramen (Cockshott and Evans 1963). Two of our patients had compression of the cord by extradural tumours demonstrated on myelography; in the third child (Patient 11) the cause might have been ischaemia of the cord (Wright 1964, 1970). With Burkitt's tumour paraplegia comes on rapidly and is usually flaccid; this helps to differentiate it from Pott's paraplegia which is usually spastic and has a slower onset (Cockshott 1970). One of our patients, however, did have a spastic paraplegia and was thought to have Pott's disease until biopsy proved otherwise. Radiologically, Burkitt's lymphoma, unlike tuberculosis, rarely involves the anterior part of the vertebral body, does not cause kyphosis and does not destroy the intervertebral disc.

The rapid response of Burkitt's lymphoma to cytotoxic drugs may be due to the high rate of proliferation of the tumour cells (Cooper, Hughes and Topping 1966; Iverson et al. 1974). At our Institute, the response to chemotherapy of patients with appendicular skeletal lesions was similar to that of patients without such lesions. More than 80 per cent of all patients treated in Uganda had a good initial response to chemotherapy, but two-thirds relapsed later (Morrow, Pike and Kisuule 1967; Burkitt 1968; Clifford 1970; Ziegler et al. 1970b; Ziegler and Kyalwazi 1971; Ziegler 1972; Olweny et al. 1976; Magrath et al. 1980). More than half of those who relapsed had long-term remissions after further chemotherapy (Ziegler, Magrath and Olweny 1979; Olweny et al. 1980). Five of our patients had long-term remissions, and were still well when last seen. The tumour is radiosensitive, but the multifocal nature of the disease precludes this form of treatment (Burkitt 1970). Chemotherapy did not delay fracture healing, and in those patients with long-term remissions, the affected bones returned to normal with no residual stigmata.

\section{REFERENCES}

Banks, PM, Arseneau JC, Gralnick HR, Canellos GP, DeVita VT, Berard CW. American Burkitt's lymphoma: a clinicopathologic study of 30 cases. II : Pathologic correlations. Am J Med 1975:58:322-9.

Berard C, O'Connor GT, Thomas LB, Torloni H et al. Histopathological definition of Burkitt's tumour. Bulletin WHO 1969;40:601-7.

Braband M. Burkitt's tumour-Klinik, epidimiologi und radiologie. Stuttgart: Thieme, 1968.

Burkitt D. A sarcoma involving the jaws in African children. Br J Surg 1958;46:218-23.

Burkitt D. Burkitt's tumour. In: Davey WW, ed. Companion to surgery in Africa. Edinburgh and London: E \& S Livingstone, 1968:7-16.

Burkitt DP. Etiology of Burkitt's lymphoma: an alternative hypothesis to a vectored virus. J Natl Cancer Inst 1969;42:19-28. 
Burkitt DP. In : Burkitt DP, Wright DH, eds. Burkitt's lymphoma. Edinburgh and London: E \& S Livingstone, 1970:43-51, 186-97.

Burkitt D, O'Conor GT. Malignant lymphoma in African children. I : a clinical syndrome. Cancer 1961;14:258-69.

Burkitt D, Wright D. Geographical and tribal distribution of the African lymphoma in Uganda. Br Med J 1966;i:569-73.

Carbone PP, Ziegler JL, Morrow R, et al. Burkitt's tumour: a comparative study in Africa and the United States. $R R C R$ 1971;36:126-36.

Clifford P. Treatment. In: Burkitt DP, Wright DH, eds. Burkitt's lymphoma. Edinburgh and London: E \& S Livingstone, 1970:52-63.

Cockshott WP. Radiological aspects of Burkitt's tumour. Br J Radiol 1965;38: 172-80.

Cockshott WP. Radiological features. In: Burkitt DP, Wright DH, eds. Burkitt's lymphoma. Edinburgh and London: E \& S Livingstone, 1970: 23-33.

Cockshott WP, Evans KT. Childhood paraplegia in lymphosarcoma (Burkitt's tumour). Br J Radiol 1963;36:914-20.

Cooper EH, Hughes DT, Topping NE. Kinetics and chromosome analyses of tissue culture lines derived from Burkitt lymphomata. Br J Cancer $1966 ; 20: 102-13$.

De-Thé G, Geser A, Day NE, et al. Epidemiological evidence for causal relationship between Epstein-Barr virus and Burkitt's lymphoma from Ugandan prospective study. Nature 1978;274:756-61.

Huckstep RL. Orthopaedic problems in East Africa. J Western Pacific Orthop Assoc 1970; 7:65-84.

Iversen OH, Iversen U, Ziegler JL, Bluming AZ. Cell kinetics in Burkitt lymphoma. Eur J Cancer 1974; 10:155-63.

Jaffe HL. Tumors and tumorous conditions of the bones and joints. London: Henry Kimpton, 1958:398.

Klein G. The Epstein-Barr virus and neoplasia. New Engl J Med 1975;293:1353-7.

Magrath IT, Lwanga S, Carswell W, Harrison N. Surgical reduction of tumour bulk in management of abdominal Burkitt's lymphoma. Br Med J 1974;11:308-12.

Magrath I, Lee YJ, Anderson T, et al. Prognostic factors in Burkitt's lymphoma: importance of total tumor burden. Cancer 1980;45:1507-15.

Morrow RH, Pike MC, Kisuule A. Survival of Burkitt's lymphoma patients in Mulago Hospital, Uganda. Br Med J 1967;iv:323-7.

O'Conor GT, Davies JNP. Malignant tumours in African children: with special reference to malignant lymphoma. J Pediatr 1960;56:526-35.

Olweny CLM, Katongole-Mbidde E, Kaddu-Mukasa A, et al. Treatment of Burkitt's lymphoma: randomized clinical trial of single-agent versus combination chemotherapy. Int J Cancer 1976;17:436-40.

Olweny CLM, Atine I, Kaddu-Mukasa A, et al. Epstein-Barr virus genome studies in Burkitt's and non-Burkitt's lymphomas in Uganda. J Natl Cancer Inst 1977;58:1191-6.

Olweny CLM, Katongole-Mbidde E, Otim D, Lwanga SK, Magrath IT, Ziegler JL. Long-term experience with Burkitt's lymphoma in Uganda. Int $J$ Cancer 1980;26:261-6.

Sabbah RS, Ali MA, Lewall DB, Aur RJA. Burkitt's lymphoma in Saudi Arabia: clinical, pathological and epidemiological analyses of 16 cases. King Faisal Specialist Hospital Med J 1982;2:77-83.

Sherman RS, Soong KY. Ewing's sarcoma: its roentgen classification and diagnosis. Radiology 1956;66:529-39.

Spjut HJ, Dorfman HD, Fechner RE, Ackerman LV. Atlas of tumor pathology. Second series, fascicle 5. Tumors of bone and cartilage. Washington DC: Armed Forces Institute of Pathology 1971:141-62.

Wright DH. Burkitt's tumour. A post-mortem study of 50 cases. Br J Surg 1964;51:245-51.

Wright DH. Gross distribution and haematology. In: Burkitt DP, Wright DH, eds. Burkitt's lymphoma. Edinburgh and London: E \& S Livingstone, 1970:64-81.

Wright DH. Epstein-Barr virus and Burkitt's lymphoma. New Engl J Med 1978;298:511.

Wynne-Davies R, Fairbank TJ. Fairbank's atlas of general affections of the skeleton. 2nd ed. Edinburgh, London and New York: Churchill Livingstone, 1976:226-7.

Ziegler JL. Chemotherapy of Burkitt's lymphoma. Cancer 1972;30:1534-40.

Ziegler JL, Cohen MH, Morrow RH, Kyalwazi SK, Carbone PP. Immunologic studies in Burkitt's lymphoma. Cancer 1970a;25:734-9.

Ziegler JL, Morrow RH Jr, Fass L, Kyalwazi SK, Carbone PP. Treatment of Burkitt's tumor with cyclophosphamide. Cancer 1970b;26:474-84.

Ziegler JL, Kyalwazi SK. Current concepts: recent research in Burkitt's lymphoma. E Afr Med J 1971;48:670-5.

Ziegler JL, Magrath IT, Olweny CLM. Cure of Burkitt's lymphoma: ten-year follow-up of 157 Ugandan patients. Lancet 1979;ii:936-8. 